\title{
Tracer Study of CIT Technology Programs Graduates
}

\author{
Dr. Karlo S. Sira \\ Dr. Dominico Sergie O. Valenciana \\ Associate Professor \\ Iloilo Science and Technology University \\ 5000 La Paz, Iloilo City \\ Philippines
}

\begin{abstract}
Tracer study is one of the primary concerns of the Higher Educational Institutions (HEIs) that documented the whereabouts of the graduates after graduation. Gines (2014) stressed that it is a powerful tool to document employment characteristics, transition characteristics and the level of satisfaction of the ISAT U-CIT graduates of 2008-2014 regarding the services, learning environment, and facilities of the University. Moreover, the tracer study also focused on the skills and competencies of the different technology programs of the College of Industrial Technology (CIT) during the pre-service training whether these programs were still valid, adequate, and relevant in responding to the dynamic world of academic programs. Furthermore, the study also benchmarked if these changes aligned to the international standards and embraced the challenges of the Commission on Higher Education (CHED) Outcome-Based Education (OBE), Institutionalization of the Philippine Qualification Framework, ASEAN 2105 integration, ASEAN Quality Reference Framework, and many others.
\end{abstract}

Keywords: Tracer Study, College of Industrial Technology, Technology programs

\section{Introduction}

"Education is the most powerful weapon which you can use to change the world."

-Nelson Mandela

The $21^{\text {st }}$ century brought numerous changes in the lives of everyone. Notably, the educational system needs to cope with the latest trends in teaching-learning processes. With these, the academe must embrace and accept these changes to become globally competitive with the expectations of the global market to produce quality graduates that are holistically competent for life-long learning. In 2014, CHED mandated all HEI to use OBE in their teaching-learning processes (CHED Handbook, 2014). The order stressed that all learning competencies within the OBE context of the vision, mission, goals, and objectives (VMGO). With this paradigm shift, the State Universities and Colleges (SUCs), undergone a series of curricular revisions in order to address the demand of the programs and the needs global market. The creation of CHED was part of a broad agenda of reforms on the country's education system to look into the uniform the composition of the Governing Boards of chartered state universities and colleges nationwide. It mandates the SUCs to coordinate and integrate the system to become more effective through the formulation and implementation of policies more relevant in their governance and ensure the enjoyment of academic freedom as guaranteed by the Constitution (CHED, 2016). Furthermore, CHED envisions to become the keystone in producing leaders system and work with the stakeholders to contribute to the nation building through its human resources.

\section{Why Tracer Study Necessary?}

In order to become a leading science and technology university in Southeast Asia by 2030, the "University is committed to provide quality and relevant advanced education, higher technological, professional instruction and training in arts, sciences, education, architecture, engineering, agriculture, forestry, and other fields of study, thereby producing locally oriented, globally competitive and eco-friendly human resources." So, the powerful tool to achieve the VMGO of the University is to trace and document employment characteristics of graduates and assess the level of satisfaction through the services offered by the University. 
The European Training Foundation (ETF) (2016) defines a tracer study as a "retrospective analyses of graduates through a standardized survey, which takes place sometime after graduation (normally between 6 months and three years). It is also known as the graduate survey, alumni survey, or graduate track. Normally, the target population is a homogenous group of students/trainees who finished their studies at the same time (generation or graduation cohort). Tracer studies are common in higher education, but are becoming more and more popular in vocational education." Furthermore, Millington (2001) in Gines (2014) states that tracer study provides quantitative structural data on employment characteristics as well as the relatedness of the competencies and retrospective assessment of the programs for curricular reforms.

Badiru and Wahome (2016), Nivera, Toledo, Sualibio, Boral, \& Asuncion (2015), and Schomburg and Ulrich (2011) stress that tracer study provides useful information for the HEI to review, revise, evaluate, and improve program offering. Through this survey on the cohort of graduates from different programs, course, highest level of education, their employment characteristics, competencies acquired and skills developed, and feedbacks from them, useful information to the University and stakeholders for curriculum enhancement for future challenges.

Lastly, the Child Labor Impact Assessment Toolkit Tracer Study Manual International Program on the Elimination of Child Labor (IPEC) (2011) revealed that the ultimate objective of a tracer study is similar to that of other impact assessments to systematically analyze the lasting or significant changes that seek to influence decisionmaking or policy formulation through the provision of empirically-driven feedback.

\section{Iloilo Science and Technology University}

The Iloilo Science and Technology University (ISAT U) considered as one of the top producers of quality and active technologists' graduates in the field of science and technology for more than a century of existence in the country and abroad. The top-caliber technologists came from the CIT of the University. After the conversion in 2013 under R. A. 10595 (2013), a strengthened eleven baccalaureate technology programs offered and two graduate programs of the CIT. Along with these, the curriculum offering and competencies shifted its paradigm from competency-based to outcome-based education, making CIT a prominent vertically articulated technological college in the University in the Region.

The conduct of the tracer study is one of the priorities in the research agenda of the University to address the call of the CHED for OBE and life-learning. It is the responsibility of the University to account its graduates of what they become after leaving the portals of their alma mater as part of educational accountability to the stakeholders. Along with these initiatives, revisions, enhance, and develop the offerings of its program to augment the needs of the K-12 enhanced basic education program of the Department of Education (DepEd). Furthermore, this endeavor wanted to determine the efficacy of the contents of the programs whether in impact to the world of work. Considering, that tracer study is one of the powerful tools for curriculum evaluation, the gathered information will suggest the weakness and the strength of the program and making the critical decision of what will be the status of the program.

Moreover, tracer studies maintained curriculum relevance and providing targeted benefits to graduates to enhance the marketability of vocational programs. Adequate knowledge on employment outcomes of vocational training graduates could assist in formulating policy towards combating some the social problems such as unemployment (Bolaane, Chuma, Toteng, \& Molwane, 2010). Further findings of the study will determine the appropriateness of the demands of the industry to the outcomes of the VMGO of the University. Findings can also be utilized to assess the status of both undergraduate and graduate programs and how these programs impacted their lives after leaving their beloved alma mater. Hence, the researchers conducted this study.

\section{Purpose of the Research}

This study sought to review and evaluate the technology programs of the CIT-ISAT U through a tracer study of its graduates from 2008-2014.

The study was designed to determine:

1. the employment characteristics in terms of (a) employment status, (b) employer, (c) tenure, (d) job position, (e) waiting time, (f) nature of work, (g) reasons for being hired, (h) present salary, (i) satisfaction of the salary, (j) job searching, (k) job location; (l) the current status in terms of (m) enrolled in upgrading course, (n) course enrolled, and (o) plan to pursue studies at the University;

2. the extent to which skills learned in school are used in the current job as a whole; and the adequacy and applicability of the program as a whole. 
Figure 1 shows the framework of the study. It depicts the variety of experiences the technology students get to prepare them to become technologist fit in the labor market. If the University delivered the proper competencies through knowledge and skills required in the workplace; the student may be able to find the right job that required specialized skill suited to their acquired competencies during their stay in the College of Industrial Technology. The CIT has 11 undergraduate specialization programs and two graduate programs namely: 1) BS in Industrial Technology major in Electronics Technology, 2) BS in Industrial Technology major in Electrical Technology, 3) BS in Hotel Restaurant Technology, 4) BS in Fashion Design and Merchandising, 5) Bachelor in Industrial Technology (BIT) major in Architectural Drafting Technology, 6) BIT Electronics Technology, 7) BIT Electrical Technology, 8) BIT Mechanical Technology, 9) BIT Heating, Ventilating, and Air-Conditioning Refrigeration Technology, 10) BIT Civil Technology, 11) BIT Fashion in Apparel Technology, 12) Master of Industrial Technology (MIT), and 13) Doctor of Industrial Technology (DIT).

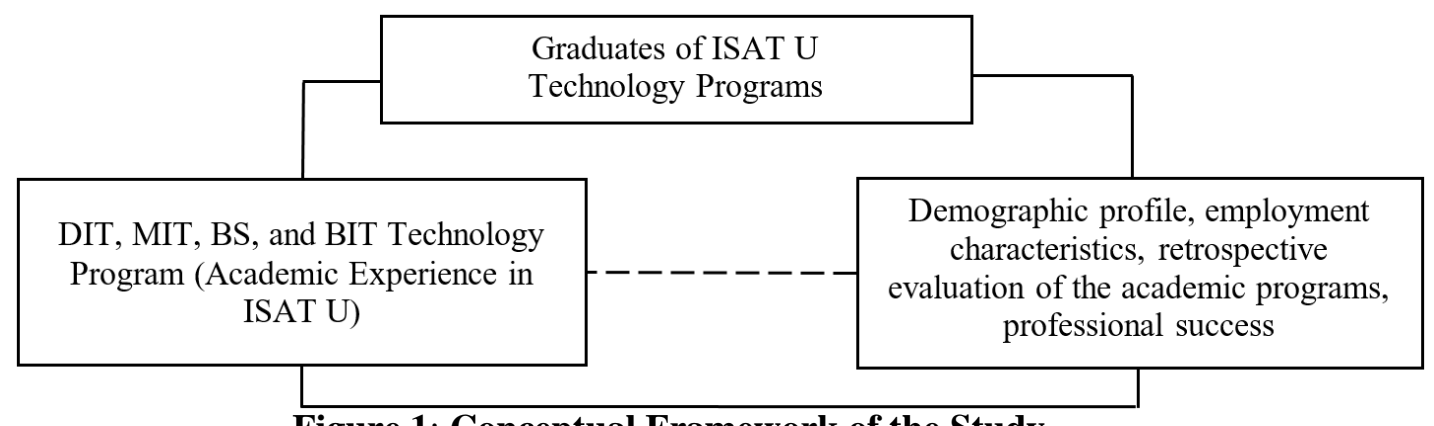

Figure 1: Conceptual Framework of the Study.

The information and feedback gathered from the tracer study would provide useful information of the whole scenario happening in each of the programs offered in CIT that could be given an immediate action for educational reforms beneficial for faculty and student. Moreover, the result provided the assessment of the curricular officering whether they still needed by the industry or not. The output of the study includes the traditional demographic profile, employment characteristics of the graduates, their retrospective assessment of the academic programs, and professional successes significantly crucial to the future of the offered programs.

\section{Methodology}

\section{Research Design}

This study used a descriptive survey including demographic profile, employment characteristics, and job satisfaction of the ISAT U graduates. It is crucial to document the evaluation of the curricular offerings on how useful, relevant, applicable, and adequate the competencies (knowledge, skills, and attitude) of the graduates have achieved the VMGO of their respective programs, the 13 CIT technology programs.

\section{Respondents and Sampling Plan}

This study was designed to obtain both qualitative and quantitative data for the graduates of 13 technology programs. Due to issues in time and logistics, the researchers opted to use snowball sampling to come up with 100 participants. It is a particular sampling technique wherein a participant of the study leads the researchers to other possible participants until the desired number is reached (Crossman, 2017). Data from the Registrar's office used for the survey. Majority of the participants are graduates from 2014 who responded through email, call interview, and hard copies. It clearly shows that the best way to track the graduates of the program is through the internet. Table 1 presents the demographic data of the participants, where the majority of them were male, not more than 30 years of age, single, came from class 2014, mostly no awards but produced cum laude, some took Licensure Examination for Teachers (LET) and passed although the program is a none-board one. 
Table 1: Demographic Data of the Participants

\begin{tabular}{|c|c|c|}
\hline Personal Information & Total $(\mathrm{N}=100)$ & $\%$ \\
\hline \multicolumn{3}{|c|}{ Sex } \\
\hline Male & 73 & 73 \\
\hline Female & 27 & 27 \\
\hline \multicolumn{3}{|c|}{ Age } \\
\hline $\begin{array}{c}\text { Not more than } 30 \text { years } \\
\text { old }\end{array}$ & 95 & 95 \\
\hline More than 30 years old & 5 & 5 \\
\hline \multicolumn{3}{|c|}{ Civil Status } \\
\hline Single & 87 & 87 \\
\hline Married & 13 & 13 \\
\hline \multicolumn{3}{|c|}{ Year Graduated } \\
\hline 2004 & 7 & 7 \\
\hline 2011 & 1 & 1 \\
\hline 2012 & 1 & 1 \\
\hline 2013 & 10 & 10 \\
\hline 2014 & 81 & 81 \\
\hline \multicolumn{3}{|c|}{ Distribution per Program } \\
\hline DIT & 4 & 4 \\
\hline MIT & 1 & 1 \\
\hline BSHRT & 9 & 9 \\
\hline BSFDM & 6 & 6 \\
\hline BS ELT & 8 & 8 \\
\hline BS ELX & 5 & 5 \\
\hline BIT FAT & 5 & 5 \\
\hline BIT MT & 6 & 6 \\
\hline BIT DT & 32 & 32 \\
\hline BIT ELT & 3 & 3 \\
\hline BIT ELX & 6 & 6 \\
\hline BIT HVACRT & 8 & 8 \\
\hline BIT CIVIL/FCT & 7 & 7 \\
\hline \multicolumn{3}{|c|}{ Honors Received } \\
\hline Cum Laude & 4 & 4 \\
\hline Other Awards & 18 & 18 \\
\hline No Award & 78 & 78 \\
\hline \multicolumn{3}{|c|}{ Examination Passed } \\
\hline LET & 7 & 7 \\
\hline CSE & 5 & 5 \\
\hline TESDA & 9 & 9 \\
\hline No Exam Taken & 79 & 79 \\
\hline
\end{tabular}

Table 1 further reflects that $18 \%$ of the participants have other awards, 5\% took Civil Service Examination (CSC), and 9\% Technical Education and Skills Development Authority (TESDA) national competency tests. It also shows the distribution of the participants per program, the majority of whom came from BIT DT program, because during the conduct AutoCAD is extensively utilized, and the internet is available in the workplace. Moreover, the provision of using social media during these years and used it to their advantage, making them the most number of the participant who responded during the conduct of the study.

\section{Instrument and Data Gathering Procedure}

A modified instrument developed by Nivera, Toledo, Sualibio, Boral, \& Asuncion (2015) and CHED format tracer study questionnaire used to obtain quantitative and qualitative data from the responses of the graduates regarding their pre-service training competencies, employment characteristics, and retrospective evaluation of the program. Timely and relevant items included in the present study done in a hard copy and online versions of the instrument. It includes 32 questions/ information such as: personal, 10; employment status, 4; current status, 4; other concerns and suggestions, 2; retrospective evaluation of the program 12. 
Before the administration of the study, the researchers secured permission from the offices of the participants and the shop owners/managers. The researchers personally distributed and collected the instrument to the identified participants. Due to problems in time and logistics, the representative from the workplace facilitated the administration and collection of the questionnaires. Some responded through phone calls and text messaging, while others answered the items in the messenger and email. Therefore, the researcher gathered 100 participants.

\section{Data Analysis}

The data gathered in this study were encoded, summarized, tabulated, processed, analyzed, interpreted and computer-processed using Statistical Package for Social Science (SPSS) Version 22. The researchers adopted a tally scheme for each item for statistical processes.

In analyzing the results, the researcher used the frequency count and percentage, mean, and standard deviation for descriptive analysis and the inferential analysis uses both t-test and One-Way ANOVA. The frequency count and percentage used established the demographic and employment profile of the participants. A thematic presentation of the results done in table and figures using the following scales and descriptions:

Rating Scale for Interpreting the Mean

\begin{tabular}{|c|c|c|c|}
\hline Range & $\begin{array}{c}\text { The extent to which } \\
\text { skill was used }\end{array}$ & $\begin{array}{c}\text { Adequacy of the course } \\
\text { content }\end{array}$ & $\begin{array}{c}\text { Applicability of the course } \\
\text { content }\end{array}$ \\
\hline $4.50-5.00$ & To a great extent & Highly adequate & Highly applicable \\
\hline $3.50-4.49$ & To some extent & Moderately adequate & Moderately applicable \\
\hline $2.50-3.49$ & To a limited extent & Not quite adequate & Not quite applicable \\
\hline $1.50-2.59$ & To a very limited extent & Slightly adequate & Slightly applicable \\
\hline $1.00-1.49$ & Not at all & Not adequate at all & Not applicable \\
\hline
\end{tabular}

The standard deviation was used to indicate the homogeneity or heterogeneity of the respondents concerning their responses. The t-test for independent samples was used to determine the significance of the difference between means of groups in two categories such as OJT centers where they were assigned. All hypotheses tested at the .05 level of significance.

\section{Results and Discussion}

During the retrieval of the instruments, the tracer graduates of the CIT Technology programs from 2008 to 2014 yielded 100 participants only due to poor response rate, and time constraints. One-half of the participants answered online, while the rest responded using hard copies. Eighty-two percent quantitatively answered the items thoroughly in the questionnaire, and $16 \%$ skipped one or more, particularly in the question on employment, income and some of the open-ended questions, which sought valuable their perception on how to improve their program.

\section{Participants' Employment Characteristics and Current Status}

Table 2 presents the participants' employment characteristics in regarding employment status which includes employment, employer, tenure, job description, waiting time, nature of work, reasons for being hired, the satisfaction of the salary, and job searching and current status of the participants concerning enrolled in upgrading at the University. 
Table 2: Participants' Employment Characteristics and Current Status

\begin{tabular}{|c|c|c|}
\hline Employment Characteristics & Total $(\mathrm{N}=100)$ & $\%$ \\
\hline \multicolumn{3}{|c|}{ Employment Status } \\
\hline Employed & 100 & 100 \\
\hline Not Employed & 0 & 0 \\
\hline \multicolumn{3}{|c|}{ Employer } \\
\hline Public & 12 & 12 \\
\hline Private & 88 & 88 \\
\hline \multicolumn{3}{|c|}{ Tenure } \\
\hline Permanent & 80 & 80 \\
\hline Casual/Contractual/Job Hire & 13 & 13 \\
\hline N/A & 7 & 7 \\
\hline \multicolumn{3}{|c|}{ Job Position } \\
\hline Supervisory & 15 & 15 \\
\hline Non-Supervisory & 85 & 85 \\
\hline \multicolumn{3}{|c|}{ Work Location } \\
\hline Iloilo & 80 & 80 \\
\hline Outside Iloilo & 14 & 14 \\
\hline Abroad & 6 & 6 \\
\hline \multicolumn{3}{|c|}{ Waiting Time to Find a Job } \\
\hline Not more 1 Year & 71 & 71 \\
\hline 2 Years & 21 & 21 \\
\hline 3 Years & 8 & 8 \\
\hline \multicolumn{3}{|c|}{ Nature of Work } \\
\hline Related & 96 & 96 \\
\hline Somewhat Related & 3 & 3 \\
\hline Not Related & 1 & 1 \\
\hline \multicolumn{3}{|c|}{ Reasons for Being Hired } \\
\hline $\begin{array}{l}\text { Knowledge and Skill Related to Work Applied } \\
\text { for }\end{array}$ & 100 & 100 \\
\hline Other Skill & 0 & 0 \\
\hline \multicolumn{3}{|c|}{ Present Salary } \\
\hline High & 74 & 74 \\
\hline Moderate & 21 & 21 \\
\hline low & 5 & 5 \\
\hline \multicolumn{3}{|l|}{ Satisfaction } \\
\hline Happy & 74 & 74 \\
\hline Quite Happy & 26 & 26 \\
\hline \multicolumn{3}{|l|}{ Job Searching } \\
\hline Recommended by Someone & 65 & 65 \\
\hline Response to Ads & 35 & 35 \\
\hline \multicolumn{3}{|c|}{ Enrolled in Upgrading at ISAT U } \\
\hline Yes & 3 & 3 \\
\hline No & 77 & 77 \\
\hline No Response & 20 & 20 \\
\hline \multicolumn{3}{|c|}{ Course Enrolled } \\
\hline Diploma in Teaching & 5 & 5 \\
\hline Post Graduate & 5 & 5 \\
\hline Skills Training/Trade Test & 16 & 16 \\
\hline N/A & 74 & 74 \\
\hline \multicolumn{3}{|c|}{ Plan to Pursue Studies at ISAT U } \\
\hline Yes & 96 & 96 \\
\hline No & 4 & 4 \\
\hline
\end{tabular}


All of the participants were employed, $80 \%$ are permanent. Most of them are working in the private sectors $(88 \%)$ and $(85 \%)$ are holding a non-supervisory position. This characteristic is very evident considering that the Technology programs are developing the student to become technologists who will be working in the private firms in the city and province of Iloilo. In King's (2012) study, people prefer to work in a place where opportunity is at reach. However, there those who wanted to work outside the country because of the offer. However, $71 \%$ of the participants waited for not more than one year to get hired for jobs related to their work. As to the salary, a majority of them is enjoying a grand scheme, happy working with their officemates. Furthermore, on job searching, most of the jobs found were recommended by someone (65\%) because of the active network established during the on-the-job training in the industry. These findings also in agreement to the study of Sira, Celda, Sobrepeña, \& Valenciana (2018) that recommendation is common to the owners and co-worker in the industry.

On the current status of the participants, $77 \%$ of whom have no plans to upgrade their course, but if given enough time and budget for the studies, they will enroll like Diploma in Teaching (DIT), either in MIT or Doctor of Education for a greener pasture. The CIT technology programs together with its competencies produced dependable and successful technologist who can become educators and engineers if planning to pursue or shift to another career. The study reveals that acquired competencies (KSA) were very significant when they wanted to pursue other fields. Those who took units in DIT claimed that their acquired competencies in the CIT programs much utilized in their teaching profession, especially in their major subjects. Moreover, those who shifted to Architecture were thankful that they have an advantage over their classmate because of what they had learned from the previous program. These findings supported by Killen (2016) that program offerings should be flexible for the students to choose to or shift from one course to another as long as they mastered the competencies. Therefore, technology programs are a strong foundation when planning to become a teacher, engineer, and an architect or even postgraduate education profession.

\section{The Extent Which Skill Learned in School Used in Current Work as a Whole}

Regarding the extent to which the participants as a whole used the skills they learned from in their current work, Table 3 shows that they used knowledge and skill to a great extent while human relation, communication, research/problem solving skills are used to some extent.

Table 3: The Extent Which Skill Learned in School Used in Current Work as a Whole

\begin{tabular}{|c|c|c|c|c|c|c|c|}
\hline \multirow[b]{2}{*}{ Skills } & (1) & (2) & (3) & (4) & $(5)$ & \multirow{2}{*}{$\begin{array}{l}\text { Weighted } \\
\text { Mean }\end{array}$} & \multirow[t]{2}{*}{ Interpretation } \\
\hline & $\begin{array}{l}\text { Not at } \\
\text { All }\end{array}$ & $\begin{array}{c}\text { Very limited } \\
\text { extent }\end{array}$ & $\begin{array}{c}\text { Limited } \\
\text { extent }\end{array}$ & $\begin{array}{c}\text { To some } \\
\text { extent }\end{array}$ & $\begin{array}{c}\text { Toa great } \\
\text { extent }\end{array}$ & & \\
\hline $\begin{array}{l}\text { Knowledge and } \\
\text { Technical Skills }\end{array}$ & 0 & 0 & 5 & 35 & 60 & 4.55 & To a great extent \\
\hline Communication Skills & 0 & 1 & 12 & 48 & 39 & 4.25 & To some extent \\
\hline Human Relation Skills & 0 & 1 & 10 & 43 & 46 & 4.34 & To some extent \\
\hline $\begin{array}{l}\text { Research / Problem - } \\
\text { solving Skills }\end{array}$ & 0 & 3 & 17 & 47 & 33 & 4.10 & To some extent \\
\hline Overall & $\mathbf{0}$ & 5 & 44 & 173 & 178 & 4.31 & To some extent \\
\hline
\end{tabular}

Research/problem-solving got the lowest ratings compared to the other skills, do time allotted for this subject. Research is one of the professional subjects in technology programs. For the technology students, they consider it as one of the hardest subjects because the output is developmental. Another reason is the lack of research skills, and no careful guidance of the adviser, and the eagerness of the group mates to finish the research. Nonetheless, they were able to finish their study before graduate. The result is in contrast to the result of the study of Gines (2014) where she found that research skills were used to a great extent. She further stressed that enough time should be allotted to complete the research on time with a dedicated research adviser.

\section{Adequacy and Applicability of the Program Content as a Whole}

Table 4 presents the adequacy and applicability of the program as a whole 
Table 4: Adequacy and Applicability of the Program as a Whole

\begin{tabular}{|l|c|c|c|c|c|c|c|}
\hline \multirow{2}{*}{ Courses } & $\mathbf{( 1 )}$ & $\mathbf{( 2 )}$ & $\mathbf{( 3 )}$ & $\mathbf{( 4 )}$ & $\mathbf{( 5 )}$ & \multirow{2}{*}{$\begin{array}{c}\text { Weighted } \\
\text { Mean }\end{array}$} & Interpretation \\
\cline { 2 - 7 } & $\begin{array}{c}\text { Not at } \\
\text { All }\end{array}$ & $\begin{array}{c}\text { Very } \\
\text { limited } \\
\text { extent }\end{array}$ & $\begin{array}{c}\text { Limited } \\
\text { extent }\end{array}$ & $\begin{array}{c}\text { To some } \\
\text { extent }\end{array}$ & $\begin{array}{c}\text { To a } \\
\text { great } \\
\text { extent }\end{array}$ & $\begin{array}{c}\text { Moderately Adequate and } \\
\text { Applicable }\end{array}$ \\
\hline Core Courses & 0 & 0 & 8 & 51 & 41 & 4.33 & $\mathbf{4}$ \\
\hline Major Courses & $\mathbf{0}$ & $\mathbf{0}$ & $\mathbf{3}$ & $\mathbf{4 0}$ & $\mathbf{5 7}$ & $\mathbf{4 . 5 4}$ & Highly Adequate and Applicable \\
\hline Professional Courses & 0 & 0 & 9 & 53 & 38 & 4.29 & $\begin{array}{c}\text { Moderately Adequate and } \\
\text { Applicable }\end{array}$ \\
\hline $\begin{array}{l}\text { General Education } \\
\text { Courses }\end{array}$ & 0 & 0 & 13 & 48 & 39 & 4.26 & $\begin{array}{c}\text { Moderately Adequate and } \\
\text { Applicable }\end{array}$ \\
\hline Overall & $\mathbf{0}$ & $\mathbf{0}$ & $\mathbf{3 3}$ & $\mathbf{1 9 2}$ & $\mathbf{1 7 5}$ & $\mathbf{4 . 3 6}$ & $\begin{array}{c}\text { Moderately Adequate and } \\
\text { Applicable }\end{array}$ \\
\hline
\end{tabular}

Interestingly, essential subjects of the technology programs were highly adequate and applicable compared to others because they specialized in nature that develops the three domains of learners. True to this, the participants claimed that the knowledge and skills learned in the University applied to their work. It revealed that their major courses designed to meet the demands of their managers. This finding reveals the objectives of the program that focused on the holistic development of the students to become a dependable and competent technologist for the industry. The result of this study conform to that of Jayathilake, Bandara, Nanayakkara, Ganepola, \& Amarasinhe, (2013) in their tracer study data shows the relevance of vocational training to self-employment by educational qualifications. Most respondents of all educational categories have mentioned that vocational training is highly relevant to their work. ETF (2016) pointed out that "tracer studies can give vital information about skills matching through the combination of objective and subjective data from the graduates." It also discussed further that apart from being able to measure the employability of graduates, and obtain feedback to improve the study program, tracer studies allow aspects of horizontal matching (relevance of field of study for the tasks done in the job) and vertical matching (appropriate position regarding the level of formal qualification) to be measured. The call for the University for providing quality competencies to students who will carry its institutional outcomes in the world of work. In confirmation, the majority of the graduate responded that they were honored, proud, and satisfied with the program of the CIT.

With their overwhelming feelings on their experience in the University, all of them would recommend it to their cohort to enroll in the technology course of the CIT. Dedicating to its quality policy statement to be "exemplary in science and technology education." Bearing its core values "ICARE (Integrity, Commitment, Accountability, Responsiveness, Excellence) that their alma mater had made proud of saying that they came from the best science and technology training institution in the country.

On the question on how to improve the CIT technology programs of the University, some participants suggested developing the soft skills as one of the demands in the fast-changing work of work. To wit:

"Upgrade the skills of the students to address the call of the Industry 4.0."

"Revisit the course offering and revise it for more appealing one."

"Upgrade the facilities of each technology programs based on the CHED requirements."

"Procure state-of-art equipment used in the absorbing industry."

"Hire competent faculty member with high morale and diverse qualifications."

Finally, the participant was very thankful and happy to have obtained there degree at the University. They believed the CIT technology programs adequately developed them into in-demand technologist in the industry.

\section{Conclusions and Implications}

This study that sought to review and evaluate the CIT Technology programs of the University through a tracer study of its graduates from 2008-2014 revealed results graduates of the programs were traceable using unique sampling technique provided useful information related to the quality of training offered to them during their stay in the program.

The participants of the study are relatively single, young, mostly male who came from class 2014 , mostly no awards but produced cum laude, some took Licensure Examination for Teachers (LET) and passed although the program is a none-board one. 
Majority of them permanently employed, working in the private sectors, with a high salary, holding a nonsupervisory position, planning to pursue or shift to other post education, and happy employee of their company. Thus, expected to be the characteristics of technology graduates who are enthusiastic to inform their University about their outcome in their respective workplace through this study. The utilization of a unique sample of the CIT technology programs gave useful information. However, critical and most important information left out there represented by other graduates of the other programs with the different set of demographic data, therefore, there is a need to trace the programs and employment transition of other groups of graduates and to incorporate the result to the present tracer study.

As to competencies, they were vital and related to the workplace through major, professional, core, and general education course, as well as skills in communication, human relations, and problem-solving, knowledge/technical, leadership and research, found to be useful and applicable to their work which advances the related of the program. There is a need to revise and enhance further the CIT technology programs to cope with the demand of the industry.

Although, problems of the physical facilities on each program, human resources were found competent and adequate. Therefore, physical improvements should make the priority of the university to increase performance and productivity. The majority of the graduates believed that the University had attained its VMGO in preparing them to become adequately competent for the labor market and instilling the love of their work and their alma mater. Furthermore, they were happy, satisfied with their salary, and harmoniously working with officemates. The initial result of the tracer study indicated the adequacy and relatedness of the programs to strengthen further by enhancing them to cope with the rapidly changing world of work. Provide state-of-the-art facilities and equipment, instructional materials, and hire highly competent faculty with diverse qualifications.

\section{Recommendations}

The researcher proposed the following recommendations based on the findings of the study:

- Include the yielded result by the present study to the university-wide tracer study with different sets of demographical data.

- Sustain the high adequacy and applicability of the program contents required in the workplace.

- Strengthen the emphasis on research/problem-solving by allotting longer time with the dedicated faculty adviser to produce research output on time and reinforce other skills such as communication, and the human relation which is also useful to some extent under the CIT technology program.

- Review and improve the CIT technology programs contents to adapt to the challenges of the modern world in science and technology.

- Improve physical facilities, instructional materials for both faculty and students

This study is limited to traceability of the employment characteristics and employment transition of the CIT technology graduates from 2008-2014 and to determine their level of satisfaction of the skills learned in the University as well as the adequacy and applicability of the programs. The researchers suggested for the expansion of the tracer study to the included assessment of the physical facilities and human resource service of the entire University and included this information to the yielded result $b$ the present study. Finally, a constant revisit of the curricular offerings every three years is encouraged to align with the practices of the workplace congruently.

\section{Acknowledgment}

The researchers extend its profound gratitude and appreciation to ISAT U Administration lead by its President, Dr. Raul F. Muyong.

\section{References}

Badiru, E. O. \& Wahome, M. (2016). Conducting Graduate Tracer Studies for Quality Assurance in East African Universities: A Focus on Graduate Students Voices on Quality Culture. Journal of Education and Practice www.iiste.org ISSN 2222-1735 (Paper) ISSN 2222-288X (Online) 7(6). Brainy Quotes (2015). Retrieved December 11, 2015, from https://www.brainyquote.com/topics/education.

Bolaane, B., Chuma, J. M., Toteng, B., \& Molwane, O. B. (2010). A Tracer Study on the Employment Outcomes of the Vocational Training Graduates, Ph. D. Retrieved November 20, 2016, from

https://unevoc.unesco.org/e-forum/BOTA_tracer-study-2010.pdf

Commission on Higher Education Portal (2014). Retrieved December 12, 2016, from https://ched.gov.ph/ 
Crossman, A. (2017). What is a Snowball Sample in Sociology? What It Is and When and How to Use It. Retrieved from https://www.thoughtco.com/snowballsampling-3026730.

European Training Foundation (2016). Tracer Studies, Evaluating the Impact of the Training Programmes. Retrieved on December 15, 2016, from https://www.etf.europa.eu/sites/default/files/m/CEDE612 F00BFF6B3C125 81A600278816_Tracer\%20studies.pdf

Executive Order No. 83 (2012). Institutionalization of the Philippine Qualification Framework. Retrieved from http://www.offcialgazette.gov.ph/2012/10/01/ executive-order-no-83-s-2012/

Flotcher, C. (2010). Address Data Bank and Website for the Graduate Survey. Kassel: INCHER-Kassel. Gines, A. C. (2014). Tracer Study of PNU Graduates. American International Journal of Contemporary Research. (4) 3, 95-96.

Herrmann D., Dilger, B. \& Junghanns, M. (2010). Specialized Questionnaires in Graduate Tracer Studies; Demand, Development and Back Channeling Results. Koln: University of Cologne.

Iloilo Science and Technology University (2015). Quality Manual. La Paz, Iloilo City, Philippines.

Iloilo Science and Technology University (2017). Curriculum Manual.

IPEC Child Labour Impact Assessment Toolkit: Tracer Study Manual / International Labour Office, International Programme on the Elimination of Child Labour (IPEC) (2011). Geneva: ILO, $2011-3$ v. Retrieved on November 20, 2016, from www.ilo.org/ipecinfo/product/download. do?type=document\&id=8990

Jayathilake, P. C. P., Bandara, H. G. K. N., Nanayakkara. P., Ganepola, M., Amarasinhe, K. T. (2013). A Tracer Study on Employability and Effectiveness of TVET Certificate Holders in 2011. Retrieved on June 23, 2017, from http://www.tvec.gov.lk/wp-content/uploads/2018/02/Employability_and_Effectiveness_of_T VET_Certificate_Holders.pdf

Killen, R. (2016). Outcomes-based Education: Principles and Possibilities. Unpublished manuscript, University of Newcastle, Faculty of Education. Retrieved from https://zombiedoc.com/outcomes-basededucationprinciples.html.

King, R. (2012). Theories and Typologies of Migration: An Overview and a Primer. Willy Brandt Series of Working Papers in International Migration and Ethnic Relations. Malmö Institute for Studies of Migration, Diversity, and Welfare (MIM). Retrieved from https:// www.mah.se/upload/Forskningsc entrum/MIM/WB/WB\%203.12.pdf.

Millington, C. (2015). The Use of Tracer Studies for Enhancing Relevance and Marketability in Online and Distance Education. Retrieved from http://wikieducator.org/images/e/e1/PID_424 pdf.

Nivera, G. C., Toledo, Z. M. G. U., Sualibio, M. F. M., Boral, Z. P. \& Asuncion, Q. O. (2015). A Tracer Study of the PNU Graduates of the BSMT and BSE Math Programs from 1985-2010. Philippine Normal University Journal of Teacher Education. (2) 7, 82-83.

R. A. 10595 (2013). An act converting Western Visayas College of Science and Technology into Iloilo Science and Technology University (ISAT U), La Paz, Iloilo City, Philippines.

Schomburg, H. \& Ulrich, T. (2011). Employability and Mobility of Bachelor Graduates in Europe: Key Results of the Bologna Process. Netherlands: Sense Publishers.

Sira, K. S., Celda, M. A. M., Sobrepeña, A. C., \& Valenciana, D. S. O. (2018). The Bachelor of Industrial Technology Major in Architectural Drafting Technology Program Tracer Study. The Normal Lights. 12(2), $1-25$.

\section{Bio note:}

KARLO S. SIRA is an associate professor of Iloilo Science and Technology University, La Paz, Iloilo City, Philippines, 5000; karlo_sira@yahoo.com. His research focuses on architectural drafting technology and industrial education. Presently he is the head of the Drawing and Drafting Technology Program and at the same time OJT supervisor.

DOMINICO SERGIE O. VALENCIANA is an associate professor of Iloilo Science and Technology University, La Paz, Iloilo City, Philippines, 5000, dsovalenciana@yahoo.com.ph. His line of interest is on architectural drafting technology and industrial education. He is the former Dean of the College of Industrial Technology and presently, Coordinator of CIT Technology Research Center. 


\section{Tracing of Graduates of College of Industrial Technology \\ (CIT) Technology Programs \\ A. Personal Information}

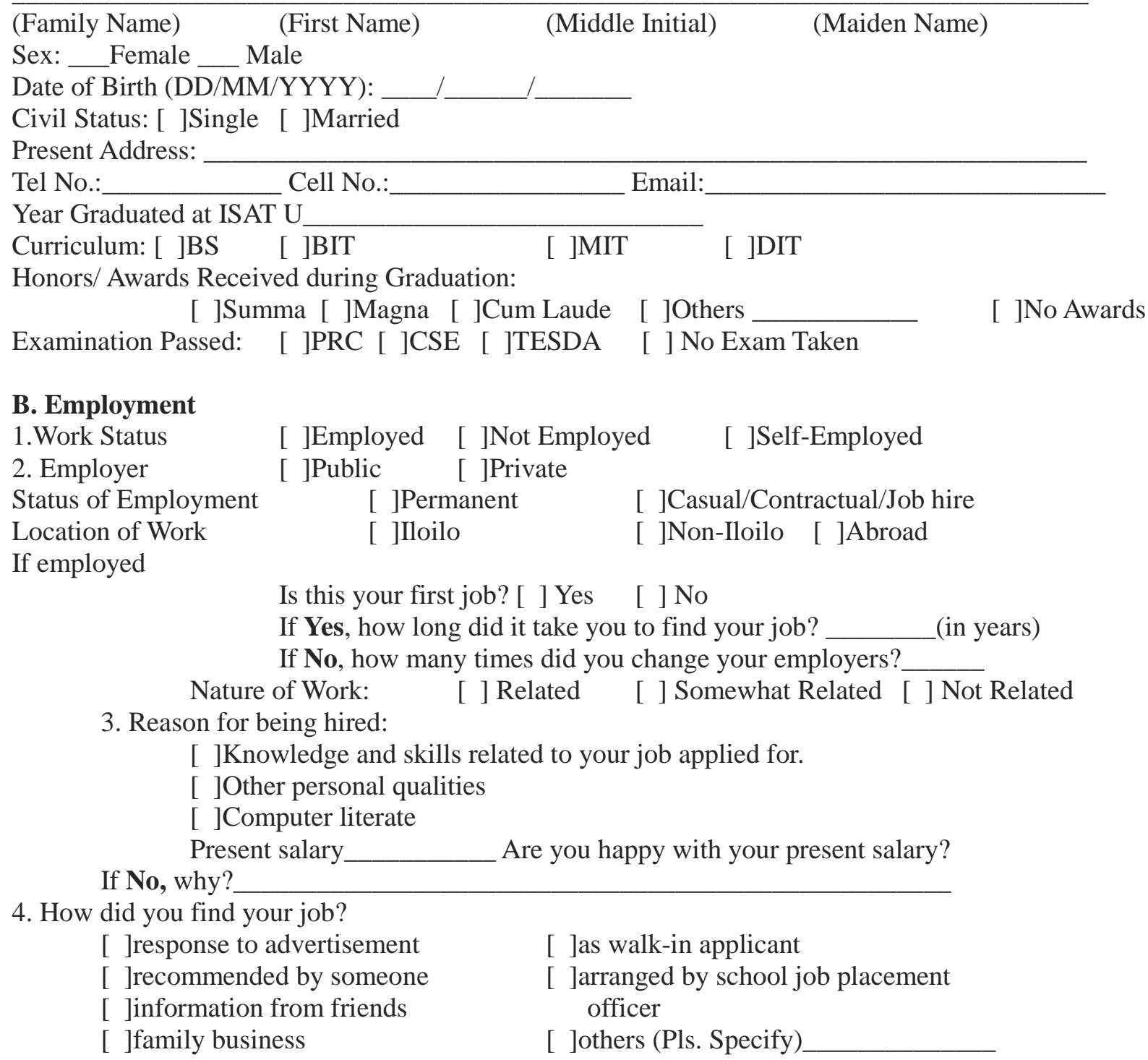

\section{Current Status}

Are you enrolled in upgrading course? [ ] Yes [ ] No

If Yes, what course? [ ]Diploma In Teaching

[ ]Skills Training/Trade Test

If No, are you planning to pursue studies at ISAT U? [ ]Yes [ ]No

If No, why?

\section{Other Concerns}

Are there some aspects of the BS/BIT/MIT/DIT programs you wanted to revise/improve?
[ ]Yes
[ ]No

If Yes, specify 


\section{E. Curriculum Assessment}

Please rate the extent to which skills learned in school are used in the current job using the following scale:

Range Interpretation

\begin{tabular}{|l|l|}
\hline $4.50-5.00$ & To a great extent \\
\hline $3.50-4.49$ & To some extent \\
\hline $2.50-3.49$ & To a limited extent \\
\hline $1.50-1.59$ & To a very limited extent \\
\hline $1.00-1.49$ & Not at all \\
\hline
\end{tabular}

Knowledge/Technical Skills

Communication Skills

$\begin{array}{ccccc}\mathbf{5} & \mathbf{4} & \mathbf{3} & \mathbf{2} & \mathbf{1} \\ {[\mathrm{]}} & {[\mathrm{]}} & {[\mathrm{]}} & {[\mathrm{]}} & {[\mathrm{]}} \\ {[\mathrm{]}} & {[\mathrm{]}} & {[\mathrm{]}} & {[\mathrm{]}} & {[\mathrm{]}} \\ {[\mathrm{]}} & {[\mathrm{]}} & {[\mathrm{]}} & {[\mathrm{]}} & {[\mathrm{]}} \\ {[\mathrm{]}} & {[\mathrm{]}} & {[\mathrm{]}} & {[\mathrm{]}} & {[\mathrm{]}}\end{array}$

\section{F. Adequacy of program content}

Please rate the adequacy of the contents taught in the BS/BIT/MIT/DIT programs using the following scale:

Range Interpretation

\begin{tabular}{|c|c|c|c|c|c|}
\hline \multicolumn{2}{|l|}{$4.50-5.00$} & \multicolumn{4}{|c|}{ Highly adequate } \\
\hline \multicolumn{2}{|l|}{$3.50-4.49$} & \multicolumn{4}{|c|}{ Moderately adequate } \\
\hline \multicolumn{2}{|l|}{$2.50-3.49$} & \multicolumn{4}{|c|}{ Not quite adequate } \\
\hline \multicolumn{2}{|l|}{$1.50-1.59$} & \multicolumn{4}{|c|}{ Slightly adequate } \\
\hline \multicolumn{2}{|l|}{$1.00-1.49$} & \multicolumn{4}{|c|}{ Not at all } \\
\hline & 5 & 4 & 3 & 2 & 1 \\
\hline General Courses & [ ] & [ ] & [ ] & [ ] & [ ] \\
\hline Major Courses & [ ] & [ ] & [ ] & [ ] & [ ] \\
\hline Professional Courses & [ ] & [ ] & [ ] & [ ] & [ ] \\
\hline Education Courses & [ ] & [ ] & [ ] & [ ] & [ ] \\
\hline
\end{tabular}

\section{G. Applicability of the Program Content}

Please rate the applicability of the contents taught in the BS/BIT/MIT/DIT programs using the following scale:

Range Interpretation

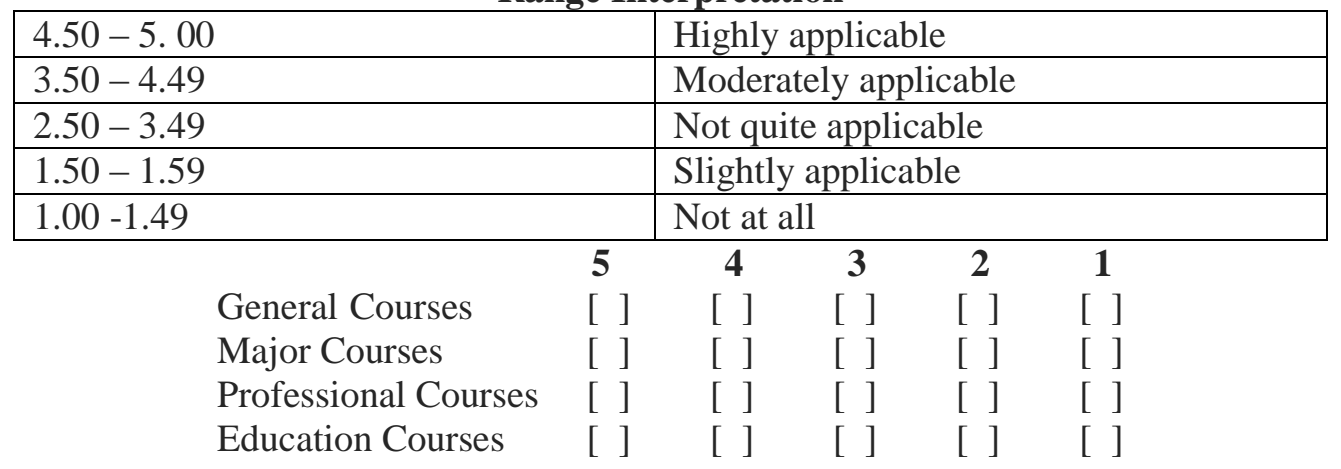

Thanking you for taking time in filling up this questionnaire. 